\author{
María Bjerg \\ Lazos rotos. La inmigración, el matrimonio y las emociones en la Argentina \\ entre los siglos XIX Y XX \\ Bernal, Editorial de la Universidad Nacional de Quilmes, 2019, 125 páginas
}

Lazos rotos se pregunta sobre el impacto de la migración en los vínculos conyugales y en las subjetividades. Coloca así un interrogante clave y casi ausente en la historiografía. Es sabido que, en general, el marido partía solo hacia América. Si los cónyuges habían convenido que la mujer y los hijos migrasen era él quien debía llamarlos y facilitarles el viaje. Si el pacto había sido el retorno el marido tenía que volver. Las cartas, las remesas y la promesa del reencuentro mitigaban el amor congelado y la intimidad en espera. Se daba por sentado que la mujer, bajo la tutela de su padre, hermanos o suegro, administraba austeramente el dinero y que el marido no la olvidaba. Si cientos de parejas reprodujeron este esquema otras tantas no pudieron sostenerlo. Es a partir de la ruptura de los acuerdos por alguno de los cónyuges, y del conflicto subsiguiente, que Bjerg bucea en la reconfiguración de los vínculos afectivos y en el impacto emocional de la migración entre las últimas décadas del siglo XIX y la Primera Guerra Mundial. Para ello se apoya en un vasto corpus documental integrado por expedientes judiciales, registros parroquiales y civiles, códigos civiles y penales, censos de población y periódicos. Con pericia la autora acorta la distancia impuesta por un océano inconmensurable y construye puentes empíricos e interpretativos entre la aldea de origen y el país receptor. En los cuatro capítulos que componen este pequeño gran libro, precedidos por una breve introducción y un corto epílogo, encarnan personajes minúsculos que en sus peripecias y felicidades cotidianas dialogan con sus propios pasados, confrontan por sus expectativas frustradas y sufren por el desmoronamiento de sus relaciones primarias. Estas experiencias son comunicables por medio de entrelazamientos complejos entre lo micro y lo macro, entre el caso y problemas sociales y culturales más amplios.

El libro se inicia con "La promesa, la espera y la traición" donde se narran historias de bígamos denunciados a la justicia por sus esposas legítimas. Luego de años de espera en la aldea de origen mujeres, solas o con sus hijos, se lanzaron a cruzar el atlántico para reencontrarse con sus maridos que las habían abandonado. Descubrieron, o ya sospechaban, que la causa de la desaparición era la bigamia. El conflicto conyugal opera como el puntapié inicial para un sutil trabajo de reconstrucción de biografías mínimas. Las emociones no preexisten en los actores y las actrices de Lazos rotos, no son estados psicológicos preexistentes, sino componentes centrales de las interacciones sociales y de los vínculos conyugales. No están "en" cada uno de los sujetos sino que surgen del contacto entre ambos y del contacto de estos con los objetos. El abandono y la traición, presente en las acciones iniciales emprendidas por las mujeres en este capítulo, son parte del quiebre conyugal, que es inescindible de un abanico de emociones en conflicto. Uno de los méritos del libro es prestar atención al conglomerado de emociones y no, como es habitual, poner el foco en una de ellas. El cariño muta en rencor y el resentimiento en ira. Un papel en apariencia anodino como la partida de matrimonio se transforma en una prueba crucial para legitimar la acusación de bigamia y se transfigura en un objeto emocional. Los objetos son nodales tanto en las relaciones que mantenemos con los otros como con nosotros mismos. Portan y generan emociones que conllevan, como es el caso de este capítulo, el tránsito entre el amor y el desafecto, la comunión y la desunión, el anhelo y el olvido.

El abandono formó parte de la experiencia migratoria y encontró en el adulterio una de sus manifestaciones. Del 
adulterio se ocupa el capítulo dos, "Quebrantar los deberes sagrados". La acusación motorizada por los hombres encuentra su espesor y legitimidad en el honor, la práctica social y el sufrimiento emocional. El honor aparece una y otra vez en Lazos rotos pues vertebra la autoridad y la reputación masculina.

Recostado en el hombre proveedor y en la fidelidad y la obediencia de la esposa, también en la obediencia de los hijos al padre, su presencia fue global. Prácticamente no hay idioma en el mundo que no le tenga una palabra reservada, y sus contenidos, como ya ha sido demostrado al menos en el lapso temporal que comprende este libro, no fueron sustantivamente diferentes en el pequeño poblado italiano o español y en una ciudad de la provincia de Buenos Aires, e incluso en la capital cosmopolita. Cuando el hombre no lograba colmar las expectativas sociales el andamiaje del honor se desmoronaba. El ímpetu con que acusaban a sus esposas obedecía a este principio y la presencia masculina en los tribunales buscaba restituir el orden moral, sexual y emocional perdido. El honor podría pensarse como una emoción en sí misma, como propone Ute Frevert, o como una noción relativamente móvil en contextos en transformación y en este libro se lo piensa con un entramado emocional mayor. El caso de Pedro Lamar (jornalero italiano que acusa a su esposa de adulterio con su hermano) muestra claramente cómo su honor masculino se entrelaza con un complejo de emociones tales como el rencor, la ira, la vergüenza, la venganza y el sufrimiento. El cuándo, dónde, entre quienes, lo que llamamos contextualización, es central para ver no solo qué emociones sino también lo que ellas significan. La información sobre órdenes de captura de la policía de la provincia de Buenos Aires que ofrece el capítulo permite ver que la mayoría de las mujeres adultas prófugas eran inmigrantes denunciadas por sus maridos y que muchas huían del sufrimiento emocional en un hogar autoritario. En una interpretación original, Bjerg propone pensar el adulterio como una vía de escape a la violencia -física y espiritualque experimentaban las mujeres. El adulterio es interpretado como la búsqueda de un refugio emocional y ofrece otra arista para retomar la pregunta central: el impacto de la migración. No es solo el de la separación de los cuerpos sino también el de las dificultades del reencuentro de los cuerpos. Cuando la pareja volvía a unirse no siempre era posible recrear la semántica y la práctica del afecto. Los expedientes judiciales de adulterio muestran el lado sombrío de la vida matrimonial en tiempos de migración y permiten indagar en las consecuencias emocionales de la movilidad espacial, las separaciones prolongadas y las esperanzas malogradas.

La convergencia del matrimonio en la Argentina podía estar plagada de tropiezos y reactualizar, modificada, la violencia doméstica anclada en supuestas o reales infidelidades, en la insubordinación femenina y en cuestiones de dinero. Es el eje del capítulo tres "Cuerpos (in) dóciles y odios cotidianos". Centrado en la reconstrucción de cuatro casos, se muestra cómo los maridos -también abogados defensores y magistrados- legitimaban la violencia verbal y física hacia las esposas apelando a su autoridad y a la educación emocional basada en la sumisión de las mujeres. Como se explicó en la comisaría, Francisco Debenedetti, denunciado por los vecinos del conventillo luego de la golpiza que propinó a su esposa Teresa, estuvo "obligado a hacerlo para evitar que la esposa mande más que él en el hogar". Sin ser un rasgo estructural del período, sostiene la autora, la violencia doméstica fue una práctica habitual en numerosos hogares. Habitual y legítima también en las páginas de los periódicos que, más allá de los matices, apenas si condenaban los excesos. Solo cuando la víctima arañó el umbral de la muerte, las crónicas usan el lenguaje de la compasión. Los acusados, también los abogados defensores y en ocasiones los jueces, preferían en los estrados apelar a la ira (a veces referida como furia o como pasión) para justificar la agresión. Cuando se trataba de las mujeres la ira no aparecía, necesariamente, como una emoción sino como una manifestación patológica. Una mujer "crispada y nerviosa", como Francisco definió a Teresa, no solo causaba la violencia conyugal, sino que justificaba, al desafiar su autoridad, la propia ira de Francisco. En un trabajo impecable de reconstrucción histórica a partir del cruce de 
documentos diversos, del cotejo de retóricas y de situaciones disímiles, se comprueba que en algunos casos la violencia devino una dinámica de la relación conyugal en la Argentina. Por ello fue, se sugiere, una de las consecuencias del costo emocional del complejo proceso de migrar.

El cuarto y último capítulo, "La pasión de los celos", explora la violencia radical sufrida por las esposas. "Uxoricidio", "homicidio" y "tragedia" eran, según los expedientes judiciales y las crónicas periodísticas consultadas por la autora, los modos de nombrar el crimen. Bjerg restituye de manera notable lenguajes, gestos, escenarios, expectativas, valores. Una configuración dinámica diseñada por la prensa, el asesino, el abogado defensor, el fiscal, el juez, los vecinos, el amante -si lo huboy el cuerpo de la víctima muestran cómo se expresaba emocionalmente la autoridad marital. A menudo la indignación, la vergüenza y los celos se transformaban en rencor y desprecio, en ira y odio. Sin manifestarse necesariamente de manera secuencial, estas emociones aparecen asociadas de algún modo con el acto final de matar. Dos ideas me parecen esenciales. La primera es que la confrontación analítica, en diferentes espacios y momentos, de los lenguajes de los actores revela que hay dominios que pueden ser emocionalmente neutros y que más allá de las diferencias de clase y de poder, los hombres veían los celos como el motor de la violencia masculina, que podían en ocasiones justificar y que usaban para explicar comportamientos masculinos. La segunda apunta a proponer que es un abanico de emociones las que hacen posible una experiencia emocional.

El uxoricidio muestra también aspectos de la dinámica de la autoridad en el hogar. Lazos rotos también muestra que la autoridad conyugal la tiene el varón, y que la mujer es su "propiedad", y ahonda en los retos que planteaban las mujeres. Si el uxoricida Ángel Fiorda dijo a la policía " $[. .$.$] que no le$ importaba nada y que la había castigado porque tenía macho" su víctima, Filomena, tampoco se privó de hacer público "que ya no quería más a su marido y sí a Cocucci”. Esta declaración, precedida de varios intentos de fuga y fugas transitorias con su amante, y de expresiones públicas de fastidio -especialmente con su cuerpo- por ejemplo, cuando su marido insistía en acariciarla frente a los vecinos expectantes, muestran que Filomena no vacilaba en desafiar en público, y también en la pieza del conventillo, a su cónyuge. Sus palabras y sus gestos no solo se daban de bruces con el concepto de autoridad y de honor hegemónico, sino que la obediencia femenina era un indicador del "cariño" que auguraba la estabilidad del vínculo conyugal. No es el amor, llamativamente, la emoción que prima en el vocabulario de los actores. Tampoco se impone como categoría analítica o como integrante necesario en una narración histórica muy cuidada y estilísticamente impecable. Se echa de menos una reflexión mayor sobre este punto, precisiones sobre su equiparación, o no, con el "cariño" (aparece como la emoción vedette en las relaciones existentes 0 imaginadas entre las parejas); sobre las razones posibles por las que no aparece casi en los escritos de los fiscales; y sobre los vínculos posibles con los usos y sentidos del amor que sabemos se encontraban en la prensa y en una parte del discurso médico y literario. ¿Tal vez la emoción del amor ampliamente idealizada, profundamente mitologizada, objetivo individual e institucionalizado en el matrimonio y la familia que proliferaba en expresiones contemporáneas al período aquí analizado; era también desafiada por estas historias tan verdaderas como trágicas?

María Bjerg saca de los "murmullos del mundo" a hombres y mujeres que cruzaron el océano para intentar una vida mejor en la Argentina. Ninguno de estos protagonistas puede ingresar en la narrativa del progreso y del ascenso que ejemplifican tantas otras biografías y corroboran datos estadísticos. Lazos rotos no pone necesariamente en entredicho esta tradición historiográfica, a la que Bjerg también ha contribuido de manera decisiva, sino que agrega otras experiencias también verdaderas. Más que contraponerse, ambas narrativas, creo, se soportan y validan mutuamente. En esta historia emocional de la migración la autora logra restituir las experiencias en su discontinuidad $\mathrm{y}$, al mismo 
tiempo, las reorganiza y las explica de manera magistral. Para ello se apoya en un minucioso trabajo de archivo, en un conocimiento bibliográfico impresionante, en una apropiación creativa del andamiaje conceptual de la "historia de las emociones" y en el propio proceso de escritura. Para aquellos interesados en las migraciones, en una perspectiva histórica de la violencia doméstica y las emociones, esto es, cómo podemos bucear en las experiencias que han originado una emoción y las formas en que son comunicadas, Lazos rotos es un libro imprescindible.

\section{Sandra Gayol}

Universidad Nacional de General Sarmiento / CONICET 